\title{
BAUDOUIN DE COURTENAY - PREKURSOR NIE TYLKO STRUKTURALIZMU
}

Słowa klucze: Jan Baudouin de Courtenay, językoznawstwo strukturalistyczne, socjolingwistyka, psycholingwistyka, etnolingwistyka, lingwistyka płci

Keywords: Jan Baudouin de Courtenay, structural linguistics, sociolinguistics, psycholinguistics, ethnolinguistics, gender linguistics

Mirosław Skarżyński był niestrudzony jako strażnik pamięci. Pasjonowała Go historia polskiego językoznawstwa, nie szczędził swego czasu i sił, by wiedza nie tylko o dokonaniach wielkich poprzedników, lecz także o kształtowaniu się ich poglądów, o intelektualnych inspiracjach i oddziaływaniach stawała się coraz pełniejsza. Zawdzięczamy Mu edycje korespondencji i prac Jana Baudouina de Courtenay, Jana Łosia, Kazimierza Nitscha, Jana Rozwadowskiego i Henryka Ułaszyna. Już bardzo chory napisał artykuł Geneza i poczatki Studium Słowiańskiego UJ (Skarżyński 2019). W ten sposób budował naszą lingwistyczną tożsamość. Szczególnie ważną postacią był dla Niego Baudouin de Courtenay. Dał temu wyraz jako edytor (Skarżyński 2007a, b, 2008, 2016; Skarżyński, Smoczyńska 2007; Baudouin de Courtenay 2011a, b), a ostatnim tematem, jakim się zajmował, była recepcja koncepcji szkoły kazańskiej w Polsce. Zainteresowanie Baudouinem motywowała

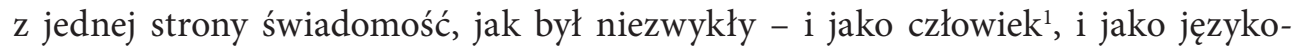

1 To właśnie o nim tak pisał Norman Davies w Bożym igrzysku... (1992: 87-88):

Był pacyfistą, zwolennikiem walki o ochronę środowiska, feministą, bojownikiem o postęp w dziedzinie edukacji i wolnomyślicielem, występował także przeciwko większości konwencji społecznych i umysłowych, jakie panowały w jego czasach. 
znawca $^{2}$, a z drugiej strony poczucie, że ciągle wiemy o tym wybitnym Polaku za mało, zbyt rzadko współcześnie sięgamy do jego dzieł, poddajemy dyskusji śmiało formułowane tezy, zadajemy sobie pytanie, ile bezpośrednio lub pośrednio zawdzięcza mu współczesna lingwistyka. A przecież już Ferdinand de Saussure wymieniał Jana Baudouina de Courtenay i Mikołaja Kruszewskiego - notabene uznając ich za językoznawców rosyjskich - jako jedynych uczonych europejskich, którzy wnieśli istotny wkład w teorię lingwistyki, i ubolewał, że są „nieznani ogółowi uczonych zachodnich" (Uwagi na temat Programu i metod językoznawstwa teoretycznego Alberta Sechehaye'go, 1908; cyt. za: Saussure 2004: 239). Sam uważnie śledził ich prace, utwierdzały go bowiem w odmiennym od młodogramatycznego rozumieniu języka i zadań językoznawstwa. Mimo że podobieństwo poglądów, a nawet sformułowań de Saussure'a i Baudouina de Courtenay uderza, to pierwszy z nich, nie zaś drugi, uznawany jest za ojca strukturalizmu. Baudouin pracował z dala od centrów naukowych $^{3}$, często publikował w językach nieznanych uczonym zachodnioeuropejskim ${ }^{4}$, a na dodatek w jego bogatym dorobku nie było dzieła, które by stanowiło systematyczny i całościowy wykład nowej teorii. Charakter taki miał Cours de linguistique générale (Kurs językoznawstwa ogólnego) (Saussure 1916), opublikowany przez Charles'a Bally'ego i Alberta Sechehaye'go w 1916 r. na podstawie notatek studentów, którzy słuchali wykładów de Saussure’a na Uniwersytecie Genewskim w latach akademickich 1906/1907, 1907/1908 i 1910/1911.

To jednak Baudouin de Courtenay, dzięki studiom w Niemczech ${ }^{5}$ doskonale znający program szkoły młodogramatycznej i sam stosujący jej metodologię (podobnie zresztą jak de Saussure), pierwszy przeciwstawił się obowiązującemu ujęciu języka -

2 Przywołam przykładowo tylko dwie opinie - Witolda Doroszewskiego i Edwarda Stankiewicza: „[...] postać Baudouina de Courtenay pozostanie na zawsze nie tylko w dziejach językoznawstwa polskiego i rosyjskiego - między te dwa narody autor dzielił swój trud życiowy - ale i w ogólnych dziejach myśli językoznawczej jako postać wielka.

Uczony jest to człowiek, w którego pobudkach postępowania chęć poznawania i rozumienia tego, co jest, dominuje nad innymi motywami. Baudouin de Courtenay był żywym wcieleniem pasji poznawczej. Jego myśl nigdy się nie zatrzymywała w dociekaniu istoty zjawisk, była jednocześnie analityczna i uniwersalna, skupiająca się na szczegółach po to, by budować z nich syntezę, tłumaczyć je i koordynować" (Doroszewski 1974: 96).

„[...] trudno jest znaleźć temat we współczesnych badaniach językoznawczych, który w ten czy inny sposób nie był inspirowany przez Baudouina i dla którego on sam nie przygotował uprzednio gruntu" (Stankiewicz 1986: 10).

3 Był profesorem uniwersytetów w Kazaniu (1875-1883), Dorpacie (1883-1893), Krakowie (18941899), Petersburgu (1900-1918) i Warszawie (1918-1929).

4 Pisał nie tylko po niemiecku, francusku i włosku, lecz także po polsku, rosyjsku, czesku i słoweńsku.

5 Były one możliwe, gdyż otrzymał dwuletnie stypendium rosyjskiego ministerstwa oświaty - podczas studiów w Szkole Głównej Warszawskiej zostały dostrzeżone jego nieprzeciętne zdolności i predyspozycje do pracy naukowej. Kontynuował naukę w Jenie (pod kierunkiem Augusta Schleichera), w Berlinie i w Lipsku, gdzie w 1870 r. uzyskał stopień doktora filozofii. 
psychofizjologicznemu, mechanistycznemu i atomizującemu. Młodogramatycy, kierując się pozytywistyczną wiarą w „nagi fakt”, koncentrowali się na konkretnych, jednostkowych aktach mowy, obserwowali zjawiska językowe, traktowane jako luźne bądź powiązane ze sobą czysto zewnętrznie. Unikanie wszystkiego, co abstrakcyjne, co wykracza poza bezpośrednie doświadczenie, prowadziło ich do utożsamienia języka ze średnią działań jednostkowych. Sama jednostka postrzegana zaś była przez nich jako pozbawiona woli, zależna od czynników fizycznych, fizjologicznych i psychicznych. Do odmiennego rozumienia języka, nie jako sumy, czyli otwartego zbioru luźnych elementów, który można w różny sposób powiększać lub zmniejszać, lecz jako systemu elementów powiązanych ze sobą rozlicznymi relacjami, doprowadziły Baudouina de Courtenay badania fonetyczne. Już w latach 7o. XIX w. uczony uważał za zasadny podział fonetyki na fonetykę akustyczno-fizjologiczną (później nazywaną antropofonika) i fonetykę właściwą. Zadaniem tej drugiej miała być analiza dźwięków w ścisłym i bezpośrednim związku ze znaczeniem wyrazów. Baudouin był pierwszym lingwistą, który dostrzegł, że „głoski i ich połączenie, w ogóle strona zmysłowa, zewnętrzna, peryferyczna języka, wzięta sama w sobie, nic nie znaczy" (cyt. za: Stankiewicz 1986: 31), gdyż dźwięki są służebne wobec „centralno-mózgowego” poziomu języka, innymi słowy - że dźwięki nie znaczą, ale mają zdolność różnicowania znaczeń. W opisie „mechanizmu dźwiękowego języka” naczelne miejsce przypadało fonemowi - jednostce abstrakcyjnej, „wspólnemu mianownikowi” dla kombinatorycznych i fakultatywnych, konkretnych wariantów dźwiękowych. Pod koniec wieku badacz postawił tezę, iż fonem jest rozkładalny na dalej już niepodzielne elementy. Było to ujęcie nowatorskie, wyprzedzające o kilkadziesiąt lat teorię cech dystynktywnych.

Baudouin utrzymywał, że język jest formą z substancją - inaczej niż de Saussure, dla którego był głównie formą - a zamiast ściśle uporządkowanego systemu relacji widział miejsce dla wahan i swobody wyboru oraz dopuszczał interferencję czynników przestrzennych, czasowych i społecznych. Sądził też, że formalne i znaczące elementy języka nieustannie na siebie oddziałują, w efekcie dając albo „pełną harmonię”, albo „nieład i chaos”, które język stara się usunąć.

W porównaniu z Saussure'owską koncepcją języka ujęcie Baudouina de Courtenay jest bardziej - można by rzec - realistyczne, bliższe złożonej rzeczywistości, nie bazuje na biegunowo przeciwstawnych pojęciach ${ }^{6}$. Nie ma w jego pracach ostrej opozycji zbiorowego langue i indywidualnego parole. Akt mowy jest przecież

6 Musimy jednak pamiętać, że Kurs... wydali koledzy de Saussure’a, którzy wprawdzie znali jego poglądy, ale nie uczestniczyli w wykładach (wykładów wysłuchała jedynie żona Alberta Sechehaye'go, z wydawcami współpracował również jeden ze studentów, Albert Riedlinger). De Saussure nie pozostawił nie tylko szkicu książki, lecz nawet systematycznych notatek do wykładów czy programu zajęć, Charles Bally i A. Sechehaye opierali się więc na notatkach dziewięciu osób, słuchaczy z różnych lat (ogółem na wykłady zapisało się dwadzieścioro dziewięcioro studentów). Z badań Roberta Godela (1957) i Rudolfa Englera (Saussure 1967-1974) wynika, że poglądy 
czynnością społeczną - przekonywał uczony - a w langue wpisane są możliwości wyboru, zakładające aktywne i twórcze nastawienie użytkownika języka. Ważne są interakcje między zachowawczą normą społeczną a twórczym, nowatorskim uczestnictwem użytkowników języka w akcie mowy. Kreatywność językową Baudouin rozumiał szeroko, uważał, że „ma miejsce nie tylko w dziedzinie składni, tj. nie polega jedynie na łączeniu gotowych słów we frazy i zdania, ale także na łączeniu morfemów w słowa" (cyt. za: Stankiewicz 1986: 46). Procesami, które - jego zdaniem - świadczą o twórczym podejściu mówiących do języka, a także o „realności” morfemów, są semantyczne interpretacje i reinterpretacje, przejawiające się np. w grach słów i „błędach” językowych dzieci, oraz wyrównania analogiczne (nazywane przezeń asymilacja morfologiczna) i etymologia ludowa. Wykazywał nietrafność koncepcji młodogramatyków:

Gdyby nie było stałej pracy twórczej psychiczno-językowej, gdyby cała nasza działalność językowa sprowadzała się tylko do naśladownictwa i odtwarzania, nie byłyby możliwe objawy podprowadzane pod pojęcie "analogii” i „słoworodu ludowego". Twórczość zaś polega na tym, że w każdej chwili działa asocjacja, czyli kojarzenie wyobrażeń przez podobieństwo, tj. na zasadzie wspólności pewnych cech, jednoczących pojedyncze okazy myślenia językowego w grupy uorganizowane i usystematyzowane (Charakterystyka psychologiczna jezyka polskiego, 1915; cyt. za: Baudouin de Courtenay 1984: 179).

Baudouinowi było więc bliskie Humboldtowskie pojmowanie języka jako dialektycznej jedności, w której nieustannie się nawzajem określają i implikują to, co indywidualne, i to, co społeczne, to, co odziedziczone, i to, co przyswojone.

Baudouin de Courtenay, podobnie jak de Saussure, rozróżniał synchronię i diachronię oraz podkreślał odrębność tych wymiarów, ale nigdy nie eksponował znaczenia jednego $\mathrm{z}$ nich. Nie przeciwstawiał ich sobie ostro, $\mathrm{z}$ synchronią wiążąc statykę, a $\mathrm{z}$ diachronią dynamikę, lecz wyróżniał prawa statyki i dynamiki, działające zarówno w synchronii, jak i w diachronii. Aspekty stałości i zmienności były dlań komplementarne. $Z$ wielką przenikliwością zauważał, że: „prawa rozwoju w czasie winny [...] być rozpatrywane jako odpowiednik praw odporności na zmianę historyczną", a „twierdzenie, iż "coś ciągle ulega zmianom", winno zostać uzupełnione twierdzeniem, iż "coś ciągle pozostaje zachowane, coś pozostaje stałe«" (cyt. za: Stankiewicz 1986: 23). W późniejszych pracach Baudouin szczegółowo zajmował się wzajemnym oddziaływaniem statyki i dynamiki - rejestrował przykłady stabilności $\mathrm{w}$ diachronii i przenikanie diachronii do synchronii. Jest to jeden $\mathrm{z}$ wielu przejawów poszukiwania przezeń ukrytych głębiej zależności, dostrzegania skomplikowanego splotu różnorodnych czynników. Również ewolucji języków nie postrzegał jako procesu linearnego, trafniejsze wydawało mu się porównanie do „przypływu i odpły-

de Saussure’a były zwykle bardziej umiarkowane, mniej skrajne niż ich rekonstrukcja przedstawiona w Kursie... 
wu morza", dopuszczał też zjawisko mieszania się języków, zachodzące w wyniku styczności geograficznej (między użytkownikami różnych języków zamieszkującymi ten sam teren lub tereny sąsiadujące) i następstwa czasowego (między różnymi pokoleniami użytkowników danego języka) ${ }^{7}$. Ewolucja języka była dla uczonego przejawem ogólnych zmian zachodzących w świecie i w życiu, wynikiem dążenia do zachowania odpowiedniości między treścią a formą.

Bardzo ważne jest także dostrzeżenie przez Baudouina de Courtenay dwu aspektów historii języka, nazwanych przezeń historią zewnętrzną i historiq wewnętrz$n q^{8}$, por.:

W historii zewnętrznej pojmujemy dany język jako całość nierozkładalną i mówimy o jej losach, tj. właściwie o losach danego zbiorowiska ludzkiego, w ten lub ów sposób ujęzykowionego. Jest to więc właściwie historia danego plemienia i narodu, rozpatrywanego ze strony wspólności myślenia językowego. [...] Taką historią zajmować się nie będziemy. Postaramy się natomiast przedstawić skrócony obraz przemian historycznych, jakie dokonywały się w ciągu wieków i w następstwie pokoleń w samym zbiorowo-indywidualnym myśleniu językowym polskim wraz z jego uzewnętrznianiem za pomocą środków świata fizycznego dla celów porozumiewania się społecznego, międzyjednostkowego. Rozłożymy przy tym to myślenie językowe polskie na jego elementy i części składowe (Zarys historii języka polskiego, 1922; cyt. za: Baudouin de Courtenay 1984: 20-21).

Baudouin de Courtenay odrzucał młodogramatyczne wyobrażenia jednolitego społeczeństwa i „przeciętnego języka narodowego", uznając je za niezgodne z rzeczywistością. W rozprawie O zadaniach językoznawstwa, opublikowanej w $1891 \mathrm{r}$., padają znamienne słowa:

Język plemienny lub narodowy jako całość, jako zbiornik wszystkiego tego, co do niego należy, co się do niego odnosi, istnieje tylko w ideale. Pojęcie pewnego języka a jego urzeczywistnianie nie idą wcale ręka w rękę. Wszystko to np., co należy do pojęcia języka narodowego, może nigdy nie było urzeczywistnionym, nigdy nie było odczutym. [...] Ponieważ zasada, podstawa języka jest czysto psychiczną, centralno-mózgową, więc językoznawstwo należy do nauk psychologicznych. Że zaś język może się urzeczywistniać tylko w społeczeństwie i ponieważ w ogóle rozwój psychiczny człowieka jest możliwy tylko w obcowaniu z innymi ludźmi, więc mamy prawo powiedzieć, że językoznawstwo jest nauką psychologiczno-socjolog iczną. Błądzą zaś ci, którzy uważając język za „organizm”, zaliczają językoznawstwo do nauk przyrodniczych (cyt. za: Baudouin de Courtenay 1984: 410, 417)9 .

7 O mieszaniu się języków pisał m.in. w rozprawach: O ogólnych przyczynach zmian językowych (1891), O pewnym stałym kierunku zmian językowych w związku $z$ antropologia (1899), O smešannom charaktere vsech jazykov (1901), Ewolucjonizm a językoznawstwo (1909).

8 Współcześnie odpowiadają temu terminy historia języka i gramatyka historyczna.

9 W tym cytacie i następnych wyróżnienia pochodzą od autora. 
Zauważając współistnienie odmian języka pełniących szczególne funkcje społeczne i ekspresywne - języków fachowych, tajnych, żargonów itd. - i postulując ich opis $^{10}$, uczony wyznaczał de facto nowy obszar badawczy, który w przyszłości miał się stać domeną socjolingwistyki.

Można go również uznać za prekursora psycholingwistyki. Związek językoznawstwa z psychologią był dla Baudouina oczywisty z powodu głębokiego przekonania badacza „o bezwzględnej psychiczności (psychologiczności) mowy ludzkiej” (Doroszewski 1974: 31). Podkreślał on, że język nie istnieje niezależnie od człowieka, że realnie istnieje tylko w jednostkach, a podstawa języka jest - powtórzmy centralno-mózgowa. Najważniejszym pojęciem w analizie procesów językowych uczynił wyobrażenie. Istotny dla Baudouina przejaw rozmaitości mowy ludzkiej, interesujący go już od czasów studiów, stanowiła mowa dziecka. W artykule Einige Beobachtungen an Kindern (1869) przedstawił uproszczenia fonetyczne i analogiczne wyrównania morfologiczne występujące u polskich dzieci. Praca ta była pionierska w zakresie badań nad kształtowaniem się i rozwojem mowy dzieci, podobnie jak kolejna, Z patologii i embriologii języka (1885-1886), w której zostały omówione zaburzenia mowy chłopca mającego wrodzoną wadę narządów artykulacyjnych. Uczony prowadził również w latach 1885-1904 obserwacje rozwoju językowego piątki własnych dzieci. Dla każdego z nich zakładał dzienniczki mowy, w których systematycznie i szczegółowo odnotowywał zachowania językowe dziecka, począwszy od pierwszych krzyków i gaworzenia aż do opanowania języka ojczystego. Materiały te (prawie 11,5 tys. stron!) mają dużą wartość ze względu na bogactwo uwzględnianych informacji ${ }^{11}$, dobrze więc się stało, że zostały już częściowo opublikowane (Baudouin de Courtenay 1974).

Nawet to, o czym była dotychczas mowa, nie pozostawia wątpliwości, że Baudouina dużo bardziej niż de Saussure’a interesowała relacja: język-człowiek-rzeczywistość, por.:

Świat cały, językowo pojęty, jest projekcją, czyli rzutem własnego „ja” na zewnątrz. Na obraz i podobieństwo swego własnego myślenia, swych stanów psychicznych człowiek usystematyzował bezwiednie rozmaitość i różnorodność zjawisk wszechświata. Człowiek włożył w świat zewnętrzny swoją psychikę, a świat zewnętrzny odbija się w psychice, [...] animizujemy świat cały, substantywizujemy, tworzymy istoty, substancje, [później zaś - A.P.] animizowane pojęcia ze świata fizycznego przenosimy na stany duszy naszej, tj. na swoje przeżywania, czucia i nastroje osobiste (Charakterystyka psychologiczna języka polskiego, 1915; cyt. za: Baudouin de Courtenay 1984: 158, 159).

10 Nieco dalej w cytowanym tekście podkreślał: „językoznawstwo jest poznawaniem i badaniem naukowym języka, czyli mowy ludzkiej w całej jej rozmaitości” (ibid.: 420).

11 Badacz wprowadził rubryki: wiek dziecka, godzina, miejsce pobytu, postawa (leży, siedzi itp.), okoliczności poprzedzające wokalizację i towarzyszące jej, zapis wokalizacji (stosował transkrypcję fonetyczną, czasem również nutowy zapis melodii), wyjaśnienie znaczenia. 
Badacz dostrzegał więc antropocentryczny charakter języka i nieprzystawanie języka do świata, co więcej - nie umknął mu paradoks polegający na tym, że na ludzi oddziałują pewne konstrukty pojęciowe, które wcześniej sami stworzyli i utrwalili w języku. Niemal przez całe swoje życie naukowe interesował się powstawaniem i oddziaływaniem stereotypów językowych, schematów poznawczych sprzęgniętych z emocjami i wartościowaniami, będących - najogólniej biorąc - wynikiem „oddziaływania myślenia językowego na psychikę, tj. na światopogląd, na nastroje itd. ludzi mówiących danym językiem” (ibid.: 215). Pytając o „wpływ języka na światopogląd i nastrój”, uczony nie tylko rozpatrywał zjawiska leksykalne, lecz także badał różne kategorie gramatyczne. Szczególnie zajmowała go problematyka językowych źródeł metafizycznych i mitologicznych przeświadczeń o rzeczywistości oraz rozróżnień rodzajowych z utrwalonymi w nich mentalnymi hierarchiami i ocenami. Twierdził, że cechą wszelkiego myślenia językowego jest dążenie do „substancjalizacji odbić świata pozajęzykowego" i tworzenie mitów językowych, ale „zabarwienie [...] myślenia rodzajowością płciową, czyli seksualną” - co uznawał za jeden z najistotniejszych skutków animizacji - nie występuje powszechnie. Niemniej jednak:
Wszystkim myśleniom językowym arioeuropejskim (oprócz ormiańskiego, o ile jest ono arioeuropejskiem) właściwa jest seksualizacja (opłciowienie) wyobrażeń językow ych, z przewagą wyobrażenia samczości, czyli z maskulinizacją (z usam- czeniem). W polskim zaś myśleniu językowym obok maskulinizacji wybujała tak- że wirylizacja (umężczyźnienie). Dla ludzi z myśleniem językowym upłciowionym cechy płciowe przyrastają do wszystkich wyobrażeń substancjalnych (rzeczowniko- wych), i trudno się tego pozbyć.
Obecność cech płciowych w wyrazie obowiązuje, a nawet może prowadzić do mitów z daleko idącymi następstwami. Dość tu wspomnieć o różnorodnych mitach, utworzonych przez różne ludy, a odnoszących się do "słońca” i „księżyca”. U jednych ludów „słońce” jest samcem, mężczyzną, a „księżyc” samicą, kobietą; u in- nych znowu odwrotnie. Stąd też różne kierunki myśli mitotwórczej (ibid.: 219).

Analizując polszczyznę, Baudouin doszedł do wniosku, że w naszym języku system rodzajowy opiera się na wielorakich opozycjach: na różnicy płci, na różnicy między płciowością a bezpłciowością, na różnicy między żywotnością a nieżywotnością i wreszcie - „na przeciwieństwie między znaczeniem społecznym mężczyzn a wszelkich innych stworzeń (łącznie z kobietami i dziećmi, o ile są wyobrażane jako dzieci" (ibid.). Dla uczonego było oczywiste, iż:

Odpowiada to pewnemu stadium w rozwoju pojęć socjalnych, a mianowicie stadium wybitnie patriarchalnemu, kiedy i żony, i dzieci, i niewolnicy stanowią własność patris familias, jako ich władcy i „głowy rodziny”, kiedy pierwiastek męski jest początkiem wszystkiego, kiedy istota najwyższa, „Bóg”, może być tylko rodzaju męskiego (ibid.: 223). 
Zasygnalizowane tu wątki w twórczości naukowej Baudouina de Courtenay pozwalają go uznać za prekursora nie tylko etnolingwistyki (lingwistyki kulturowej, antropologicznej), lecz także lingwistyki feministycznej (lingwistyki płci) ${ }^{12}$.

Na koniec warto przynajmniej wspomnieć o postulacie Baudouina, by do językoznawstwa wprowadzać „coraz więcej myślenia ilościowego, myślenia matematycznego", dzięki czemu będzie możliwe zbliżenie się do nauk ścisłych. Sformułowania użyte w artykule Ilościowość w myśleniu językowym (1927):

jedyną metodą o podłożu matematycznym, stosowaną dotychczas w językoznawstwie, jest metoda statystyczna. Inne pojęcia matematyczne w zastosowaniu do myślenia językowego tylko się przybliżenie zaznacza, ale się ich jeszcze systematycznie nie stosuje (Baudouin de Courtenay 1984: 442)

wyraźnie sugerują, że uczony nie wątpił, iż kiedyś będzie inaczej. Tak istotnie się stało. W latach 50. XX w. wykształciła się lingwistyka matematyczna, z niej wyłoniła się lingwistyka algebraiczna, pojawiło się wiele propozycji sformalizowanego opisu i modeli języka naturalnego, a narzędzia matematyczne są stosowane przez różne nurty językoznawstwa ${ }^{13}$.

12 Ponieważ jeden z Recenzentów (obu serdecznie dziękuję za lekturę mojego tekstu) nie tylko mocno w to wątpi, lecz wręcz potraktował tę tezę jako „anachronizm w odniesieniu do przełomu XIX i XX w.", czuję się w obowiązku dodać choć kilka szczegółów. Baudouin czynnikami społeczno-kulturowymi tłumaczył wiele faktów językowych: alternację tematów w M l.mn. przymiotników i zaimków (np. dobrzy/dobre, starzy/stare, oni/one, sami/same, którzy/które), różne formy liczebników (np. dwaj, trzej, czterej / dwie, trzy, cztery; dwóch, trzech, czterech / dwie, trzy, cztery), formalną morfologiczną wirylizację wyrazów i wyrażeń odnoszących się nie tylko do mężczyzn, lecz także do kobiet (np. kto, ktokolwiek, w każdym z nas, człowiek, obywatele, Polacy, Francuzi), kierunek derywacji (np. sąsiad/sąsiadka, wuj/wujna, wujenka, wójt/wójtowa, wójtówna, Rogoszl Rogoszowa, Rogoszanka, Jan/Janowa, Janówna), występowanie "gramatycznie nieskoordynowanych połączeń" typu doktor Zawadzka itd. W rozprawach naukowych Baudouina natrafiamy na sformułowania, pod którymi by się podpisały współczesne feministki - przywołam tylko przykłady z cytowanej powyżej pracy: „odróżnianie mężczyzn od reszty świata”, „utonięcie kobiet nie tylko w nazwiskach, ale nawet w imionach mężów”, „kobiety pojmuje się zawsze jako dodatek albo do ojca, albo też do męża”, „Zgodnie z poglądami społecznymi, skrystalizowanymi w dekalogu, a stawiającymi kobietę, »żonę«, obok wołu, osła, domu i innych rzeczy, kobieta, jako coś pochodnego, zajmuje stanowisko podrzędne i usuwa się na plan dalszy" (ibid.: 220, 221-222, 222, 223). A zatem uczony ukazywał odbicie w polszczyźnie społecznej podrzędności kobiet - korespondowało to z jego działaniami na rzecz ich równouprawnienia.

Na zainteresowanie Baudouina triadą język-człowiek-rzeczywistość wpływ mogła mieć myśl Wilhelma von Humboldta, bardzo przezeń cenionego. Ostatnio przypomniał o tym Piotr Sobotka w referacie Wilhelm von Humboldt, Jan Baudouin de Courtenay i Ferdinand de Saussure: pochodzenie i rozwój nowożytnej myśli lingwistycznej, inspiracje, wygłoszonym na Zjeździe Polskiego Towarzystwa Językoznawczego w Częstochowie (16-17 IX 2019 r.). Baudouin uważał Humboldta za prekursora „nowszego językoznawstwa »filozoficznego«, czyli ogólnego”, jego dzieła zaś określił epitetem "nieśmiertelne”.

13 Nie miejsce tu, by rozwijać ten temat, zasygnalizuję więc jedynie, że w językoznawstwie występują nawiązania m.in. do: matematyki statystycznej, rachunku prawdopodobieństwa, teorii mnogości, 
W krótkim szkicu dało się dotknąć zaledwie kilku zagadnień - bogactwo myśli Baudouina de Courtenay zachęca do ciągłych powrotów. Był on przecież autorem kilkuset prac naukowych z zakresu różnych dziedzin nauki o języku. Przyczynił się do powstania lub rozwoju wielu subdyscyplin językoznawczych, m.in.: fonologii, morfologii, morfonologii, gramatyki historycznej języka polskiego, gramatyki porównawczej języków słowiańskich, onomastyki, językoznawstwa ogólnego, klasyfikacji genologicznej i typologicznej, teorii pisma. Interesowały go również zastosowania językoznawstwa, np. glottodydaktyka, retoryka, nauczanie pisania i czytania osób głuchoniemych, przydatność dociekań etymologicznych i semantycznych w badaniach historycznokulturowych. W roku 2029 minie sto lat od śmierci Baudouina. Dla Profesora Skarżyńskiego było oczywiste, że musimy dobrze wykorzystać czas dzielący nas od jubileuszu - robić wszystko, by powszechna stała się świadomość, jak wielkiego formatu był uczonym. Warto też wracać do publicystyki Baudouina, zwalczającego uprzedzenia rasowe, narodowościowe i polityczne, zawsze stającego po stronie słabszych, krzywdzonych i wykorzystywanych, apelującego o wzajemny szacunek.

\section{Literatura}

Baudouin De Courtenay J.N., 1869, Einige Beobachtungen an Kindern, „Beiträge zur vergleichenden Sprachforschung", t. 6, s. 215-222.

Baudouin de Courtenay J.N., 1885-1886, Z patologii i embriologii języka, „Prace Filologiczne" I, z. 1, s. 14-58; z. 2-3, s. 318-344.

Baudouin de Courtenay J.N., 1891, O ogólnych przyczynach zmian językowych, „Prace Filologiczne" III, s. 447-488.

Baudouin de Courtenay J.N., 1899, O pewnym stałym kierunku zmian językowych w związku z antropologia, „Kosmos” z. 4-5, s. 155-173.

BAudouin de Courtenay J.N., 1901, O smešannom charaktere vsech jazykov, „Žurnal Ministerstva Narodnogo Prosveščenija” nr 337, s. 12-24.

Baudouin de Courtenay J.N., 1909, Ewolucjonizm a językoznawstwo, „Myśl Niepodległa” nr 89, s. 222-232.

Baudouin de Courtenay J.N., 1974, Spostrzeżenia nad językiem dziecka, wybór i oprac. M. Chmura-Klekotowa, Wrocław.

Baudouin de Courtenay J.N., 1984, O języku polskim. Wybór prac, red. J. Basara, M. Szymczak, Warszawa.

logiki matematycznej, kombinatoryki, teorii grafów, topologii ogólnej i teorii kategorii. Przykładowo można wymienić: gramatykę generatywno-transformacyjną Noama A. Chomsky'ego, gramatykę kategorialną typu identyfikacyjnego (teoria Jehoszui Bar-Hillela), gramatykę kategorialną opartą na zasadach matematycznej teorii mnogości (koncepcja Olgi S. Kulaginy), gramatykę zależności i projekcyjności (teoria Davida G. Haysa), moskiewski model „Sens $\leftrightarrow$ Tekst”, model języka autorstwa praskiego zespołu Petra Sgalla. 
Baudouin de Courtenay J.N., 2011a, Listy Jana Niecisława Baudouina de Courtenay do Kazimierza Nitscha (1905-1928), [w:] A. Czelakowska, M. Skarżyński (red.), Materiały do dziejów polskiego językoznawstwa. Listy Jana Niecisława Baudouina de Courtenay, Jana Łosia, Kazimierza Nitscha, Jana Michała Rozwadowskiego, Henryka Ułaszyna, „Biblioteka LingVariów”, t. 8, Kraków, s. 29-74.

Baudouin de Courtenay J.N., 2011b, Listy Jana Niecisława Baudouina de Courtenay do Jana Michała Rozwadowskiego (1908-1919), [w:] A. Czelakowska, M. Skarżyński (red.), Materiały do dziejów polskiego językoznawstwa. Listy Jana Niecisława Baudouina de Courtenay, Jana Łosia, Kazimierza Nitscha, Jana Michała Rozwadowskiego, Henryka Ułaszyna, „Biblioteka LingVariów”, t. 8, Kraków, s. 75-99.

Davies N., 1992, Boże igrzysko. Historia Polski, przeł. E. Tabakowska, t. 2: Od roku 1795, wyd. 2, Kraków.

Doroszewski W., 1974, Jan Baudouin de Courtenay - językoznawca i myśliciel, [w:] J.N. Baudouin de Courtenay, Dzieła wybrane, t. 1, Warszawa, s. 9-97.

Godel R., 1957, Les sources manuscrites du „Cours de linguistique générale” de F. de Saussure, Genève - Paris.

Saussure F. DE, 1916, Cours de linguistique générale. Publié par Charles Bally et Albert Sechehaye avec la collaboration de Albert Riedlinger, Lausanne - Paris.

SAussure F. DE, 1967-1974, Cours de linguistique générale, wyd. krytyczne, red. R. Engler, Wiesbaden.

SAUSSURE F. DE, 2004, Szkice z językoznawstwa ogólnego, przeł., wstęp i red. M. Danielewiczowa, Warszawa.

Skarżyński M., 2007a, Nieznane listy Jana Baudouina de Courtenay do Kazimierza Nitscha z lat 1905-1928. Cz. I: 1905-1910, „LingVaria” nr 1 (3), s. 167-190.

SKARŻYŃsKi M., 2007b, Nieznane listy Jana Baudouina de Courtenay do Kazimierza Nitscha $z$ lat 1905-1928. Cz. II: 1911-1928, „LingVaria” nr 2 (4), s. 149-174.

Skarżý́ski M., 2008, Nieznane listy Jana Baudouina de Courtenay do Jana M. Rozwadowskiego, „LingVaria” nr 1 (5), s. 205-232.

SKARŻý́ski M. (oprac.), 2016, Materiały do dziejów polskiego językoznawstwa. II: Jan Baudouin de Courtenay. Teksty mniej znane, „Biblioteka LingVariów”, t. 21, Kraków.

SkARŻYŃski M., 2019, Geneza i początki Studium Słowiańskiego UJ, „LingVaria” nr 1 (27), s. 11-33, https://doi.org/10.12797/LV.14.2019.27.01.

SkARżý́ski M., Smoczyńska M. (red.), 2007, Listy Jana Baudouina de Courtenay do Henryka Ułaszyna z lat 1898-1929, „Biblioteka LingVariów”, t. 1, Kraków.

StankiewiCz E., 1986, Baudouin de Courtenay a podstawy współczesnego językoznawstwa, Wrocław - Warszawa - Kraków - Gdańsk - Łódź.

\section{Baudouin de Courtenay: A Precursor of More than Structural Linguistics Summary}

The paper contrasts Jan Baudouin de Courtenay's approach to language with Neogrammarian views on the one hand, and Ferdinand de Saussure's approach on the other. Similarly to the Swiss linguist, de Courtenay understood language as a system, but his views on the langue-parole and synchronydiachrony relationships were more complex. He can also be considered a precursor of sociolinguistics, psycholinguistics, ethnolinguistics, and even gender linguistics. 